\title{
DIAGNOSTIC VALUE OF FIBRONECTIN AND MIR-122 TARGETS AN ANTI- APOPTOTIC GENE IN EGYPTIAN PATIENTS WITH HEPATOCELLULAR CARCINOMA AND CHRONIC HEPATITIS
}

\author{
Shaden H. Muawia ${ }^{1}$, Hala H. El-Said ${ }^{2}$, Ashraf Y. Elfert ${ }^{2}$ and Tarek M. Kamel ${ }^{1, *}$ \\ 1 Department of Molecular Biology, Genetic Engineering and Biotechnology Research Institute, \\ Sadat City University, Egypt \\ ${ }^{2}$ Department of Clinical Biochemistry, National Liver Institute, Menofiya University, Egypt \\ * Corresponding author:
}

Tel.: 01006859052 ; E-mail address : tarek kamellab@yahoo.com .

\begin{abstract}
Circulating miR-122 is commonly deregulated in liver fibrosis and hepatocellular carcinoma. Fibronection (FN) has been related to liver fibrosis in chronic liver disease. This study examined whether circulating levels of miR-122 regulates tumorigenesis in hepatocellular carcinoma by targeting $\mathrm{Bcl}-\mathrm{w}$. Also in this study we tried to examine whether circulating level of miR-122 and FN can be used as noninvasive markers for liver injury in Egyptian patients with chronic hepatitis $\mathrm{C}$ virus infection, in addition tried to explore the potential usefulness of serum miR-122 and FN as a diagnostic markers of HCV-related hepatocellular carcinoma (HCC). Out of 84 participants; 20 patients were HCV positive infected patients, $44 \mathrm{HCC}$ patients infected with $\mathrm{HCV}$, and 20 healthy volunteers were also included. We determined the expression of levels of miR-122 and Bcl-w in serum using (qRT-PCR). In addition, the level of plasma FN was measured quantitatively by (ELISA). Mean miR-122 expression levels were up-regulated in both patient groups compared to control group. Conversely, mean Bcl-w expression levels were down-regulated in both patients groups compared to control group. In addition, mean levels of plasma FN were significantly higher in Patient groups as compared to control group $(p=<0.001)$. Furthermore, expression levels of miR-122 and FN were positively correlated with ALT, AST, ALP and fibrosis stage, and negatively correlated with prothrombin concentration and Albumin in both patient groups. By analyzing the diagnostic performance of the studied parameters among patient groups; the combined use of FN and miR-122 achieved (sensitivity $84 \%$ and specificity $70 \%$ ) for the differentiation of HCC from HCV patients and (sensitivity $81 \%$ and specificity $77 \%$ ) for the differentiation of patients with early fibrosis from those with significant fibrosis. Conclusion: This study shed light on the functions of miR-122 which may act as an endogenous apoptosis regulator and thus negatively regulates tumorigenesis. Also this study concluded that miR-122 and FN can be used as novel biomarkers for liver injury and may be used to discriminate patients with HCC from HCV.
\end{abstract}

Key words: Micro RNA-122, Bcl-w, Fibronectin, Chronic hepatitis, Hepatocellular carcinoma and Hepatitis C virus.

\section{INTRODUCTION}

Hepatitis $\mathrm{C}$ virus (HCV) is considered the most common etiology of chronic liver disease in Egypt (Czepiel et al. , 2008) .Hepatocellular carcinoma (HCC) is the commonest primary liver cancer with increasing incidence to become the 5th commonest malignancy worldwide and the third leading cause of cancer-related death (Bosch et al., 2004).In Egypt, between 1993 and 2002 there was an almost twofold increase in HCC among chronic liver patients, HCC was reported to account for about $4.7 \%$ of chronic liver disease patients (El-Zayadi et al., 2005). The most common condition associated with hepatocarcinogenesis is cirrhosis which develops 20 to 40 years of chronic liver disease. It has been reported that not only increased cellular proliferation but also, diminished cell death play important roles in hepatocarcinogenesis and tumor progression in HCC (Befeler et al., 2003). Hepatic fibrosis, defined as excessive accumulation of extracellular matrix components, develops after chronic liver injury mainly due to chronic viral hepatitis B and C, alcoholism and fatty liver disease (Schuppan et al., 2008). Liver fibrosis may progress to liver cirrhosis, the end-stage liver disease, which has been a globally increasing major health problem with high mortality and 
morbidity in the past twenty years (Bataller et al., 2005). Liver biopsy is the gold standard for the grading and staging of fibrosis. However, this invasive technique has a mortality rate of 0.1 $0.01 \%$ and harbors the risk of severe complications (Bedossa et al. , 2003) .Measurement of liver stiffness using transient elastography can detect severe fibrosis (NguyenKhac et al. , 2006) but this technique is hampered by several limitations (e.g., ascites, obesity, cholestasis, hepatic inflammation) (Koch et al. 2011). In recent years microRNAs (miRNAs), a family of short (average of 20 25 nucleotide long), naturally occurring, small non-coding RNAs have emerged as important post-transcriptional regulators of gene expression (Borchert et al., 2006) miRNAs are predicted to control the activity of more than $60 \%$ of all protein-coding genes (Friedman et al., 2009) It has been estimated that miRNAs regulate up to $30 \%$ of human genes. Like mRNAs, some miRNAs also show restricted tissue distribution; for example, miRNA-122 is highly enriched in liver, whereas miR-124 is preferentially expressed in neurological tissues (Garzon et al., 2009). Recent studies have identified several miRNAs as key players in virus-host interactions, during $\mathrm{HCV}$ infection it has been demonstrated that a liver-specific miRNA, miR-122, binds to the $5^{\prime}$ nontranslational region of hepatitis $C$ virus (HCV) genomic RNA and is essential for HCV replication in human hepatoma-derived Huh7 cells (Jopling et al. , 2005). MiR-122 down-regulation has been reported in rodent and human HCCs (Gramantieri et al., 2007) suggesting that its function is associated with hepatocarcinogenesis. In HCC-derived cell lines, miR-122 directly targets cyclin G1 (CCNG1) by binding its $3^{\prime}-$ UTR. An inverse correlation between miR-122 and CCNG1 exists in primary liver carcinoma, further emphasizing the importance of miR-122 in HCC pathogenesis (Gramantieri et al., 2007). In vertebrates; each miRNA has been predicted to target 200 transcripts (Krek. et al., 2005). A search for other miR-122 regulatory targets that may be involved in the progression of HCC using online prediction algorithms has identified $\mathrm{Bcl}-\mathrm{w}$, which is an anti-apoptotic Bcl-2 family member (Gibson et al., 1996). Fibronectin (FN) is a noncollagenous extra cellular matrix glycoprotein and one of the factors that promotes wound healing through its facilitating effects of cell adhesion or migration ( Hynes et al. , 1980), in arterial walls, fibronectin can be produced by endothelial cells, smooth muscle cells and fibroblasts and exists in all layers of the walls. Fibronectin also plays important roles in the development and pathogenesis of many disorders, including cancer. It has also been mentioned that fibronectin plays important roles in hepatic fibrogenesis (Proctor et al., 1980).

The present work aimed to examine whether circulating levels of miR-122 regulates tumorigenesis in hepatocellular carcinoma by targeting $\mathrm{Bcl}-\mathrm{w}$. Also in this study we tried to examine whether circulating level of miR-122 and FN can be used as noninvasive markers for liver injury in chronic hepatitis C virus infection, in addition tried to explore the potential usefulness of serum miR-122 and $\mathrm{FN}$ as a diagnostic markers of HCV-related hepatocellular carcinoma (HCC).

\section{PATIENTS AND METHODS}

This study was carried out on 84 participants. Sixty- four patients were recruited between May 2014 and August 2014 from National liver Institute Menofiya University, Egypt. Twenty healthy volunteers were also included. This study was approved by the research review committee of the Menofiya faculty of Medicine. And all the studied subjects gave their informed consent. The studied subjects were classified into 3 main groups: Group I Included 20 patients with chronic hepatitis $\mathrm{C}$ virus infection (HCV). They were 12 males and 8 females; their ages were ranged from 31 to 71 years old. Group II Included 44 Patients with hepatocellular carcinoma (HCC); who were associated with $\mathrm{HCV}$. They were 28 males and 16 females; their ages were ranged from 35 to 74 years old. All subjects included in the study were negative for HBs Ag. Exclusion criteria: The patients with known history of autoimmune diseases, diabetes mellitus, chronic inflammatory disease and a history of cancer other than hepatocellular carcinoma, as well as patients with chronic liver disease not HCV related were excluded. Group III is the control group which included 20 healthy volunteers with matched age and sex were chosen carefully, the subjects of this group with no evidence of liver disease and who were negative for HCV antibodies.

All patients were subjected to the following:

A-Through history taking and complete clinical examination with stress on; jaundice, hepatomegaly, ascites, splenomegaly, lower limb oedema, and encephalopathy.

B-Abdominal ultrasound; to assess the echo pattern and size of the liver and the presence of 
periportal fibrosis, the presence of ascites, the size of spleen or any other abnormalities .

C-Abdominal triphasic CT scanning and or MRI were performed for patients as well as liver biopsy and histopathological examination whenever possible.

D-METAVIR score was used to stage liver fibrosis (F0-F4) (Paynord et al., 1997) .Liver fibrosis was scored on a 5-point scale: F0, no fibrosis; F1, portal fibrosis alone; F2, portal fibrosis with rare septae; F3, portal fibrosis with many septae; F4, cirrhosis. The presence of stage F0-F1 was termed minimal or early fibrosis; the presence of stage F2-F4 was termed significant fibrosis; whereas the term advanced fibrosis was reserved for stage F3-F4.

E - Laboratory investigations including:

1. Liver function tests [Total Bilirubin, Albumin, Alanine aminotransferase (ALT), Aspartate aminotransferase (AST), alkaline phosphatase (ALP) and prothrombin time (PT)].

2. Anti HCV antibodies (third generation) by microparticle enzyme immunoassay (MEIA) technology on Axsym was performed for all participants. Positive cases followed by RTPCR (Reverse transcription polymerase chain reaction) for confirmation of $\mathrm{HCV}$ infection and estimation of total viremia (Morishima et al., 2006).

3. Quantitative determination of alphafetoprotein (AFP) Using chemiluminescence technique on Cobas e 411 from Roche (Germany) (Sato et al., 1993).

4. Quantitative determination of human Fibronectin by Enzyme-Linked Immunosorbant Assay (ELISA) (Jung et al., 1986).

5. Quantitative determination of serum miR122 expression level using q RT- PCR assay.

6. Quantitative determination of human serum Bcl-w expression level using q RTPCR assay.

\section{Samples collection:}

Approximately $7 \mathrm{~mL}$ of venous blood was taken from the subjects and healthy controls. Five $\mathrm{ml}$ of each blood sample was transferred to plain vacutainer tubes, the sample allowed to clot for 30 minutes and then centrifuged for 15 minutes at $3000 \mathrm{rpm}$. The clear supernatant serum was separated from the clot and some used for liver function tests and AFP, and some was stored in aliquots at $-80{ }^{\circ} \mathrm{C}$ for miR-122 and Bcl-w determination. The remaining $2 \mathrm{~mL}$ was in vacutainer trisodium citrate tube for determination of prothrombin time and FN .All laboratory studies were performed at National Liver Institute, department of clinical biochemistry.

Quantitative determination of serum miR-122 expression level using q RT- PCR assay:

Total RNA Extraction: According to the manual by Qiagen

Frozen serum samples were thawed. Then $200 \mu \mathrm{l}$ from serum was added to $1 \mathrm{ml}$ QIAzol Lysis Reagent. The mixture was mixed.200 $\mu \mathrm{l}$ chloroform was added to the tube containing the homogenate and closed securely. The tube was vortexed.The tube containing the homogenate was placed on the bench top at room temperature for 2-3 $\mathrm{min}$. The homogenate was centrifuged for $15 \mathrm{~min}$ at $12,000 \times \mathrm{g}$ at $4 \stackrel{\circ}{\circ} \mathrm{C}$. After centrifugation, the sample was separated into 3 phases: an upper, colorless, aqueous phase containing RNA; a white interphase; and a lower, red, organic phase. The upper aqueous phase was transferred to a new collection tube. 1.5 volumes of $100 \%$ ethanol were added and mixed. Up to $700 \mu$ l of the sample was Pipetted, into an RNeasy Mini spin column in a $2 \mathrm{ml}$ collection tube. The flow-through was discarded. $700 \mu \mathrm{l}$ Buffer RWT was added to the RNeasy Mini spin column. The lid was closed gently and centrifuged for $15 \mathrm{~s}$ at $\geq 8000 \times g$ to wash the column. The flow through discarded. 500 $\mu \mathrm{l}$ Buffer RPE was pipetted onto the RNeasy Mini spin column. The lid gently was closed and centrifuged for $15 \mathrm{~s}$ at $\geq 8000 \times g$ to wash the column. The flow through was discarded. The RNeasy Mini spin column was placed into a new 2 $\mathrm{ml}$ collection tube, and the old collection tube was discarded with the flow-through. The RNeasy Mini spin column was transferred to a new $1.5 \mathrm{ml}$ collection tube. 30-50 $\mu \mathrm{l}$ RNase-free water was pipetted directly onto the RNeasy Mini spin column membrane. The lid was closed gently and centrifuged for $1 \mathrm{~min}$ at $\geq 8000 \times \mathrm{g}$ to elute the total RNA. Then the total RNA was aliquoted into two aliquots; one for RT- PCR of miR-122 and the other one for RT-PCR of Bcl-w.

Reverse Transcription (RT) and Quantitative PCR (q PCR) (Chen, C. et al. , 2005)

1-Prepare the RT reaction master mix: The expression levels of miRNA-122 and its house keeping gene miR-16 were measured by quantitative RT-PCR. To prepare the RT master mix using the TaqMan ${ }^{\circledR}$ MicroRNA Reverse transcription Kit components: $20 \mathrm{X}$ or $60 \mathrm{X}$ RT primers were diluted to a $5 X$ working stock 
solution using $0.1 \mathrm{X}$ TE buffer. The primer sequence for miR-122 gene was the following: Forward 5' -GACAAGCCTGGCTACTGTGTT-3'. And Reverse 5' -GTGGCCCATCTTGTCCTTC-3'. miR-16 was used as internal control. The primer sequence of miR-16 gene was as follow: Forward 5'-TAGCAGCACGTAAATATTGGCG-3'.And

Reverse 5'-TGCGTGTCGTGGAGTC- 3'.

In a polypropylene tube, the RT master mix was prepared as follow: $0.15 \mu \mathrm{l} 100 \mathrm{mM}$ dNTPs , 1.00 $\mu \mathrm{l}$ MultiScribe $^{\mathrm{TM}}$ Reverse Transcriptase, $50 \mathrm{U} / \mathrm{\mu l}$, $1.50 \mu \mathrm{L} 10 \times$ Reverse Transcription Buffer , $0.19 \mu \mathrm{l}$ RNase Inhibitor, $20 \mathrm{U} / \mu \mathrm{l}$ and $4.16 \mu \mathrm{l}$ Nuclease-free water in a final volume of $7.00 \mu \mathrm{l}$. Each $15-\mu \mathrm{L}$ RT reaction consists of $7 \mu \mathrm{l}$ master mix, $3 \mu \mathrm{l}$ of $5 \times \mathrm{RT}$ primers, and $5 \mu \mathrm{RNA}$ sample. Mixed gently and centrifuged to bring the solution to the bottom of the tube.

2- Perform reverse transcription (cDNA Synthesis): To program the thermal cycler : 30 $\min$ at $1^{\circ} \mathrm{C}, 30 \mathrm{~min}$ at $42^{\circ} \mathrm{C}, 5 \mathrm{~min}$ at $85^{\circ} \mathrm{C}$, and then maintained at $4^{\circ} \mathrm{C}$. The reaction volume was set to $15.0 \mu \mathrm{l}$. The reaction tube or plate was loaded into the thermal cycler. Then the RT run was started.

3-Prepare the q PCR reaction mix: A sterile 1.5$\mathrm{mL}$ microcentrifuge tube was obtained for each sample. And the following components were pipetted into each tube: $1.00 \mu \mathrm{l}$ TaqMan $\AA$ Small RNA Assay (20X), $1.33 \mu \mathrm{l}$ Product from RT reaction , $10 \mu \mathrm{l}$ TaqMan $\AA$ Universal PCR Master Mix II (2X) and $7.67 \mu \mathrm{l}$ Nuclease-free water in a total volume $20 \mu \mathrm{l}$. The tube was capped and inverted several times to be mixed. Then the tube was centrifuged briefly.

4-Prepare the PCR reaction plate: $20 \mu$ of the complete q PCR reaction mix was transferred into each of three wells on a 48-, or 96-, or 384-well plate. The plate was sealed with the appropriate cover. Then the plate was centrifuged briefly, and was loaded into the instrument.

5-Set up the experiment or plate document and run the plate: Thermal Cycling Conditions: All reactions were run on the 7500 (Applied Biosystems, USA) using the following conditions: $95^{\circ} \mathrm{C}$ for $10 \mathrm{~min}$, followed by 40 cycles at $95^{\circ} \mathrm{C}$ for $15 \mathrm{~s}$, and $60^{\circ} \mathrm{C}$ for $1 \mathrm{~min}$. The run was started. Melting curve analysis was performed at the end of PCR cycles in order to validate the specificity of the expected PCR product. Relative quantitation (RQ) of miR-122 was calculated using the comparative cycle threshold (CT) $\left(2^{-\Delta \Delta C T}\right)$ method (Schmittgen et al., 2008).

\section{Quantitative determination of human serum Bcl-w expression level using q RT- PCR assay: cDNA Reaction Preparation: According to the manual by Applied Biosystems}

To prepare The 2X RT Master Mix (Per $20 \mu \mathrm{L}$ reaction):The volume of components needed to prepare the required number of reaction was calculated by referring to the following: $2.0 \mu \mathrm{L} 10 \mathrm{X}$ RT Buffer, $0.8 \mu \mathrm{L} 25 \mathrm{X}$ dNTP Mix (100mM), 2.0 $\mu \mathrm{L}$ 10X RT Radom Primers , $1.0 \mu \mathrm{L}$ MultiScribe TM Transcriptase , $1.0 \mu \mathrm{L}$ RNase Inhibitor , $3.2 \mu \mathrm{L}$ Nuclease-free $\mathrm{H} 2 \mathrm{O}$, in a total volume $10.0 \mu \mathrm{L}$ per reaction. The PCR primers for $\mathrm{Bcl}-\mathrm{w}$ gene were the following sequence: $\mathrm{Bcl}-\mathrm{w}$ forward $5{ }^{\circ}$ CACCCAGGTCTCCGATGAAC3'. and reverse 5'TTGTTGACACTCTCAGCACAC3'. The housekeeping gene $\beta$-actin was used as endogenous control. $\beta$-actin forward and reverse primers were 5'AGCGAGCATCCCCCAAAGTT 3'. And 5'GGGCACGAAGGCTCATCATT 3"; respectively.

To prepare the cDNA Reverse Transcription reactions: $10 \mu \mathrm{L}$ of $2 \mathrm{XRT}$ master mix was pipetted into each well of 96 -well reaction plate. $10 \mu \mathrm{L}$ of RNA sample (previously obtained from total RNA extraction step) was pipetted into each well, pipetting was done up and down two times to mix. The plate was sealed. The plate was briefly centrifuged to spin down the contents and to eliminate any bubbles. To program the thermal cycling conditions: The thermal cycler was programmed using the conditions below: $25 \stackrel{\circ}{\circ} \mathrm{C}$ for 10 min., $37^{\circ} \mathrm{C}$ for $120 \mathrm{~min}$., $85^{\circ} \mathrm{C}$ for $5 \mathrm{~min}$. and then maintained at $4 \stackrel{\circ}{\circ}$.

Quantitation of Bcl-w by q RT PCR: (Saikiet al. , 1988)

A sterile $1.5-\mathrm{mL}$ microcentrifuge tube was obtained for each sample. And the following components were pipetted into each tube: $12.5 \mu \mathrm{l}$ Power SYBR $\AA^{\circ}$ Green PCR Master Mix (2X), $1 \mu \mathrm{l}$ (12.5p mol) forward primer , $1 \mu \mathrm{l}(12.5 \mathrm{p} \mathrm{mol})$ reverse primer, $5 \mu \mathrm{l}$ template and $5.5 \mu \mathrm{l}$ water in a total volume $25 \mu \mathrm{l}$. The tube was capped and inverted several times to be mixed. The tube was centrifuged briefly. Thermal cycling conditions for quantitation : $10 \mathrm{~min}$. at $95{ }^{\circ} \mathrm{C}$ ( DNA polymerase activation) and PCR cycling step (40 cycles) 15 sec. at $95{ }^{\circ} \mathrm{C}$ (denature), followed by $1 \mathrm{~min}$. at 60 oC (anneal/extend). Relative expression (RQ) of Bcl-w was calculated using the comparative cycle threshold (CT) $\left(2^{-\Delta \Delta C T}\right)$ method (Schmittgen et al., 2008).

Statistical analysis was carried out using SPSS version 20 . Values were expressed as mean $\pm S D$, 
Kruskal-Waills and Mann-Whitney tests were used. Spearman's correlations were done between different parameters. ROC curves discriminating patients with $\mathrm{HCC}$ from $\mathrm{HCV}$ and patients with early fibrosis from those with significant fibrosis. $X^{2}$ was obtained by ChiSquare test. $P$ value was considered significant when $\leq 0.05$.

\section{RESULTS AND DISCUSSION}

Eighty four individuals were enrolled in the study. Sixty four patients were admitted to National liver Institute Menofiya University, Tropical medicine and Oncology departments. Twenty healthy volunteers were also included. The_studied subjects were classified into: Group I: 20 patients with HCV infection. They were $(60 \%$ males, $40 \%$ females) with age ranged from 31 to 71 years old. Group II: 44 patients with hepatocellular carcinoma ( $\mathrm{HCC})$, who were associated with $\mathrm{HCV}$ infection. They were $(63.6 \%$ males, 36.4 females) with age ranged from 35 to 74 years old. Group III: 20 healthy volunteers with no liver disease. They were $(70 \%$ males and $30 \%$ females) with age ranged from 31 to 69 years old. The different stages of liver fibrosis (F0-F4) were assessed by fibroscan and were distributed among patient groups as follow: In HCV group $[F 0=2(10 \%), F 1=4(20 \%), F 2=4(20 \%), F 3=4(20 \%)$, and $\mathrm{F} 4=6(30 \%)]$. And in $\mathrm{HCC}$ group $[\mathrm{FO}=0(0 \%)$ $, F 1=0(0 \%) \quad, \quad F 2=8(18.2 \%), \quad F 3=14(31.8 \%) \quad$ and $\mathrm{F} 4=22(50 \%)]$. Results obtained presented in tables 1-7 and figures 1-14. (table 1) and (figure 1) show demographic data of studied patients. A highly significant increase in ALT, AST, ALP and total bilirubin were detected in both patient groups compared to controls. While, serum albumin, prothrombin concentration were significantly decreased. AFP serum levels were significantly increased in all patients groups as compared to control group, its levels in HCC patients was significantly higher than HCV patients without HCC. Serum miR-122 expression level (RQ) in $\mathrm{HCV}$ group (GI) was significantly elevated than HCC (GII) ( $P=0.025)$. Serum level of $B c l-w(R Q)$ in HCC group (GII) was highly significantly elevated than HCV (Gl) $(P<0.001)$. Fibronectin level was highly significantly elevated in $\mathrm{HCV}$ infected patients (GI) and HCC (GII) than control (GIII) $(P<0.001)$. As represented in (figure 2) and showed in (table 2).

Mean level of plasma fibronectin was significantly elevated in patients with significant fibrosis compared to those with early fibrosis $(P=0.011)$.While, mean expression level of miR- analysis were done to evaluate the values of circulating miR-122 and FN levels for

$122(R Q)$ was not significantly elevated in significant fibrotic group compared to early fibrotic group of patients $(p=0.152)$. As represented in (figure 3), and showed in (table 3). Plasma Fibronectin and serum miR-122 levels were increased with increasing of fibrosis stage until F3 and then slight drop in their levels occur in F4. (Data not shown (

The data from patient groups (HCV and HCC) showed that miR-122 expression levels were positively correlated with ALT, AST, ALP, total viremia, fibronectin and fibrosis stage. And it was in a negative significant correlation with Prothrombin concentration and $\mathrm{Bcl}-\mathrm{w}$. Fibronectin was in a positive significant correlation ALT, AST, ALP, miR-122 and total viremia .And it was in a negative significant correlation with albumin and prothrombin time. As represented in (figures 4-12) and showed in (tables 4, 5).

\section{Receiver Operating Characteristic (ROC)} Curve analysis :ROC curve analysis was designed for miR-122 and FN in HCV infected patients against HCC group of patients. ROC curve was performed as cut off for disease progression. The area under the curve and the best cut off values (c.o.v.) and youden index of miR-122 and FN levels were obtained from the sensitivity and specificity \% in progression of malignancy (Hilden et al., 1996).The results showed that the cut off for FN was $199 \mu \mathrm{g} / \mathrm{ml}$; at sensitivity $77.27 \%$ and specificity $60 \%$, while the sensitivity and specificity for miR-122 were $63.64 \%$ and $75 \%$, respectively. The combined use of $\mathrm{FN}(77.27 \%)$ as well as miR-122 (63.64\%) achieved the highest sensitivity (84.09\%) making them as useful tool for screening HCC patients. The overall combined sensitivity; specificity, Positive Predictive Value (PPV) and negative predictive value (NPV) are represented in (figure 13), and showed in (table 6). The areas under the (ROC) curve of fibronectin and miR-122 for discriminating patients with $\mathrm{HCC}$ from $\mathrm{HCV}$, and its $p$ values were 0.673 and $0.705 \quad(P=0.005$, $\mathrm{P}=0.007$ ), respectively. While the combined use of miR-122 and FN presented a significant urea under the curve of 0.727 and $P=0.007$. As represented in (figure 13), and showed in (table 6). (Table 6) represented the risk estimate at a relative miR-122 and FN cut off values 3.85 /199, after calculating the positive and negative predictive values. A significantly elevated relative 
risk by 5.286 folds more for developing

malignancy after $\mathrm{HCV}$

infection.

Table 1: Demographic characteristics of subjects enrolled in the study

Table 2: miR-122, Bcl-w, FN and total viremia among studied groups

\begin{tabular}{|c|c|c|c|}
\hline Parameter & $\begin{array}{c}\text { Gl } \\
\mathrm{HCV} \\
\mathrm{N}=20\end{array}$ & $\begin{array}{c}\text { GII } \\
\mathrm{HCC} \\
\mathrm{N}=44\end{array}$ & $\begin{array}{c}\text { GIII } \\
\text { Control } \\
\mathrm{N}=20\end{array}$ \\
\hline \multicolumn{4}{|l|}{$\begin{array}{l}\text { T. blirubin } \\
\text { (mg/dl) }\end{array}$} \\
\hline Mean & 1.37 & 2.99 & 0.68 \\
\hline SD & 0.63 & 2.26 & 0.10 \\
\hline $\begin{array}{l}F \\
P\end{array}$ & \multicolumn{3}{|c|}{$\begin{array}{c}51.0 \\
<0.001^{*}\end{array}$} \\
\hline Sig. with & 2,3 & 1,3 & 1,2 \\
\hline \multicolumn{4}{|l|}{ ALT (U/L) } \\
\hline Mean & 85.1 & 81.41 & 25.1 \\
\hline SD & 38.73 & 46.14 & 5.04 \\
\hline $\mathrm{F}$ & \multirow{2}{*}{\multicolumn{3}{|c|}{$\begin{array}{c}45.47 \\
<0.001^{*}\end{array}$}} \\
\hline$P$ & & & \\
\hline Sig. with & 3 & 3 & 1,2 \\
\hline \multicolumn{4}{|l|}{ AST (U/L) } \\
\hline Mean & 81.2 & 107.5 & 28.3 \\
\hline SD & 37.4 & 48.8 & 5.41 \\
\hline$F$ & \multirow{2}{*}{\multicolumn{3}{|c|}{$\begin{array}{c}26.9 \\
<0.001^{*}\end{array}$}} \\
\hline$P$ & & & \\
\hline Sig. with & 2,3 & 1,3 & 1,2 \\
\hline \multicolumn{4}{|l|}{$\overline{A L P}(\mathrm{U} / \mathrm{L})$} \\
\hline Mean & 258.3 & 462.0 & 145.1 \\
\hline SD & 76.4 & 236.6 & 27.6 \\
\hline $\mathrm{F}$ & \multirow{2}{*}{\multicolumn{3}{|c|}{$\begin{array}{c}57.3 \\
<0.001^{*}\end{array}$}} \\
\hline$P$ & & & \\
\hline Sig. with & 2,3 & 1,3 & 1,2 \\
\hline \multicolumn{4}{|l|}{$\begin{array}{c}\text { Albumin } \\
(\mathrm{g} / \mathrm{dl})\end{array}$} \\
\hline Mean & 3.68 & 3.16 & 4.55 \\
\hline SD & 0.58 & 0.43 & 0.32 \\
\hline $\mathrm{F}$ & \multirow{2}{*}{\multicolumn{3}{|c|}{$\begin{array}{c}66.3 \\
<0.001^{*}\end{array}$}} \\
\hline$P$ & & & \\
\hline Sig. with & 2,3 & 1,3 & 1,2 \\
\hline \multicolumn{4}{|l|}{ PT (Sec.) } \\
\hline Mean & 12.88 & 15.8 & 11.27 \\
\hline SD & 1.5 & 2.9 & 0.30 \\
\hline $\mathrm{F}$ & \multirow{2}{*}{\multicolumn{3}{|c|}{$\begin{array}{c}31.57 \\
<0.001^{*}\end{array}$}} \\
\hline$P$ & & & \\
\hline Sig. with & 2,3 & 1,3 & 1,2 \\
\hline \multicolumn{4}{|l|}{$\operatorname{AFP}(n g / m l)$} \\
\hline Mean & 8.18 & 1964.3 & 2.67 \\
\hline SD & 5.25 & 1955.5 & 1.2 \\
\hline$F$ & \multirow{2}{*}{\multicolumn{3}{|c|}{$\begin{array}{c}65.3 \\
<0.001^{*}\end{array}$}} \\
\hline$P$ & & & \\
\hline Sig. with & 2,3 & 1,3 & 1,2 \\
\hline
\end{tabular}

\begin{tabular}{|c|c|c|c|}
\hline Parameter & $\begin{array}{c}\boldsymbol{G I} \\
\mathbf{H C V} \\
\mathrm{N}=20\end{array}$ & $\begin{array}{c}\boldsymbol{G I I} \\
\mathbf{H C C} \\
\mathrm{N}=44\end{array}$ & $\begin{array}{c}\text { GIII } \\
\text { Control } \\
\mathrm{N}=20\end{array}$ \\
\hline $\begin{array}{c}\text { miR-122 (RQ) } \\
\text { Copies/ml }\end{array}$ & & & \\
\hline Mean & 9.12 & 5.68 & ------- \\
\hline SD & 7.83 & 4.16 & ------- \\
\hline $\begin{array}{l}\mathrm{F} \\
\mathrm{P}\end{array}$ & \multicolumn{3}{|c|}{------ } \\
\hline Sig. with & 2 & 1 & $\begin{array}{l}------ \\
\end{array}$ \\
\hline \multicolumn{4}{|l|}{$\begin{array}{c}\text { Bcl-w (RQ) } \\
\text { Copies } / \mathrm{ml}\end{array}$} \\
\hline Mean & 0.26 & 0.55 & ------- \\
\hline SD & 0.21 & 0.28 & ------- \\
\hline $\begin{array}{l}\mathrm{F} \\
\mathrm{P}\end{array}$ & \multicolumn{3}{|c|}{${ }^{-------}$} \\
\hline Sig. with & 2 & 1 & ------- \\
\hline \multicolumn{4}{|l|}{$\begin{array}{c}\text { Fibronectin } \\
(\mu \mathrm{g} / \mathrm{ml})\end{array}$} \\
\hline Mean & 191.05 & 166.23 & 119.7 \\
\hline SD & 47.53 & 36.39 & 19.3 \\
\hline $\begin{array}{l}\mathrm{F} \\
\mathrm{P}\end{array}$ & \multicolumn{3}{|c|}{$\begin{array}{c}31.4 \\
<0.001^{*}\end{array}$} \\
\hline Sig. with & 3 & 3 & 1,2 \\
\hline \multicolumn{4}{|l|}{$\begin{array}{c}\text { Total viremia } \\
(\text { Copies } / \text { ml x103) }\end{array}$} \\
\hline Mean & 996.21 & 1490.43 & $\begin{array}{l}------ \\
\end{array}$ \\
\hline SD & 743.51 & 838.3 & ------- \\
\hline $\begin{array}{l}\mathrm{F} \\
\mathrm{P}\end{array}$ & \multicolumn{3}{|c|}{$0.017^{*}$} \\
\hline Sig. with & 2 & 1 & ------- \\
\hline
\end{tabular}

SD: Standard Deviation, F: Test Value, P: Over all P value, miR-122: micro RNA-122, $\mathrm{P}$ is considered significant when $\mathrm{P} \leq 0.05$

ALT: Alanine aminotransferase, AST:

Aspartate aminotransferase, ALP:

Alkaline phosphatase, PT: Prothrombin time,

AFP, Alpha-fetoprotein, SD: Standard

Deviation, F: Test Value, $\mathrm{P}$ : Over all $\mathrm{P}$ value, $\mathrm{P}$

is considered significant when

$\mathrm{P} \leq 0.05$

Table 3: Fibronectin level and miR-122(RQ) group and significant among early fibrosis fibrosis group

\begin{tabular}{|c|c|c|}
\hline Parameter & $\begin{array}{c}\text { Early Fibrosis } \\
(\text { F0-F1) } \\
(\mathbf{n}=6)\end{array}$ & $\begin{array}{c}\text { Significant Fibrosis } \\
(\text { F2-F4) } \\
(\mathbf{n}=58)\end{array}$ \\
\hline \multicolumn{3}{|l|}{$\begin{array}{c}\text { Fibronectin } \\
(\mu \mathrm{g} / \mathrm{ml})\end{array}$} \\
\hline Mean & 136.67 & 177.84 \\
\hline SD & 9.31 & 41.61 \\
\hline $\begin{array}{l}\mathrm{F} \\
\mathrm{P}\end{array}$ & \multicolumn{2}{|c|}{$0.011^{*}$} \\
\hline Sig. with & $\begin{array}{c}\text { Significant } \\
\text { Fibrosis }\end{array}$ & Early Fibrosis \\
\hline \multicolumn{3}{|l|}{$\begin{array}{c}\operatorname{miR-122}(\mathrm{RQ}) \\
(\text { Copies/ml) }\end{array}$} \\
\hline Mean & 2.80 & 7.16 \\
\hline SD & 1.32 & 5.86 \\
\hline $\begin{array}{l}\mathrm{F} \\
\mathrm{P}\end{array}$ & \multicolumn{2}{|c|}{0.152} \\
\hline & & \\
\hline
\end{tabular}


Table 4: Correlation of miR-122, AFP, total viremia, fibronectin and fibrosis stage, in HCV infected patients

\begin{tabular}{|c|c|c|c|c|c|c|c|c|c|c|}
\hline \multirow{2}{*}{ Parameters } & \multicolumn{2}{|c|}{$\mathbf{m i R - 1 2 2}(\mathbf{R Q})$} & \multicolumn{2}{|c|}{ AFP } & \multicolumn{2}{c|}{ Total viremia } & \multicolumn{2}{c|}{ Fibronectin } & \multicolumn{2}{c|}{ Fibrosis stage } \\
\cline { 2 - 11 } & $\mathbf{r}_{\mathbf{s}}$ & $\mathbf{p}$ & $\mathbf{r}_{\mathbf{s}}$ & $\mathbf{p}$ & $\mathbf{r}_{\mathbf{s}}$ & $\mathbf{p}$ & $\mathbf{r}_{\mathbf{s}}$ & $\mathbf{p}$ & $\mathbf{r}_{\mathbf{s}}$ & $\mathbf{p}$ \\
\hline T. Bilirubin & -0.116 & 0.627 & $0.467^{*}$ & 0.038 & -0.055 & 0.819 & 0.079 & 0.741 & 0.111 & 0.640 \\
\hline Albumin & 0.094 & 0.692 & -0.436 & 0.054 & 0.033 & 0.889 & $-0.497^{*}$ & 0.026 & $-0.512^{*}$ & 0.017 \\
\hline ALT & $0.603^{*}$ & 0.005 & 0.103 & 0.666 & $0.739^{*}$ & $<0.001$ & $0.612^{*}$ & 0.004 & $0.644^{*}$ & 0.002 \\
\hline AST & $0.548^{*}$ & 0.012 & 0.079 & 0.741 & $0.697^{*}$ & 0.001 & $0.733^{*}$ & $<0.001$ & $0.694^{*}$ & 0.001 \\
\hline ALP & $0.633^{*}$ & 0.003 & 0.224 & 0.342 & $0.745^{*}$ & $<0.001$ & $0.660^{*}$ & 0.002 & $0.675^{*}$ & 0.001 \\
\hline PT & $-0.499^{*}$ & 0.025 & -0.236 & 0.316 & $-0.626^{*}$ & 0.003 & $-0.513^{*}$ & 0.021 & $-0.610^{*}$ & 0.004 \\
\hline Bcl-w (RQ) & $-0.585^{*}$ & 0.007 & -0.055 & 0.819 & $-0.703^{*}$ & 0.001 & -0.357 & 0.122 & -0.297 & 0.203 \\
\hline miR-122 (RQ) & 1.000 & - & -0.359 & 0.120 & $0.913^{*}$ & $<0.001$ & $0.669^{*}$ & 0.001 & $0.778^{*}$ & $<0.001$ \\
\hline AFP & -0.359 & 0.120 & 1.000 & - & -0.170 & 0.475 & -0.297 & 0.204 & -0.124 & 0.603 \\
\hline Total viremia & $0.913^{*}$ & $<0.001$ & -0.170 & 0.475 & 1.000 & - & $0.678^{*}$ & 0.001 & $0.706^{*}$ & 0.001 \\
\hline Fibronectin & $0.669^{*}$ & 0.001 & -0.297 & 0.204 & $0.678^{*}$ & 0.001 & 1.000 & - & $0.885^{*}$ & $<0.001$ \\
\hline
\end{tabular}

AFP: Alpha-fetoprotein, AST: Aspartate aminotransferase, ALT: Alanine aminotransferase. PT: Prothrombin time, ALP: Alkaline phosphatase, $P$ is considered significant when $P \leq 0.05$

Table 5: Correlation of miR-122, AFP, total viremia, fibronectin and fibrosis stage, in HCC patients

\begin{tabular}{|c|c|c|c|c|c|c|c|c|c|c|}
\hline \multirow{2}{*}{ Parameters } & \multicolumn{2}{|l|}{$\mathbf{m i R - 1 2 2}(\mathbf{R Q})$} & \multicolumn{2}{|c|}{ AFP } & \multicolumn{2}{c|}{ Total viremia } & \multicolumn{2}{|c|}{ Fibronectin } & \multicolumn{2}{|c|}{ Fibrosis stage } \\
\cline { 2 - 11 } & $\mathbf{r}_{\mathbf{s}}$ & $\mathbf{p}$ & $\mathbf{r}_{\mathbf{s}}$ & $\mathbf{p}$ & $\mathbf{r}_{\mathbf{s}}$ & $\mathbf{p}$ & $\mathbf{r}_{\mathbf{s}}$ & $\mathbf{p}$ & $\mathbf{r}_{\mathbf{s}}$ & $\mathbf{p}$ \\
\hline T.Bilirubin & -0.127 & 0.410 & $0.371^{*}$ & 0.013 & 0.021 & 0.890 & -0.117 & 0.451 & 0.156 & 0.313 \\
\hline Albumin & $-0.299^{*}$ & 0.049 & -0.031 & 0.842 & $-0.425^{*}$ & 0.004 & $-0.323^{*}$ & 0.033 & $-0.375^{*}$ & 0.044 \\
\hline ALT & $0.424^{*}$ & 0.004 & 0.271 & 0.075 & $0.298^{*}$ & 0.050 & $0.492^{*}$ & 0.001 & $0.308^{*}$ & 0.042 \\
\hline AST & $0.441^{*}$ & 0.003 & 0.082 & 0.598 & $0.470^{*}$ & 0.001 & $0.559^{*}$ & $<0.001$ & $0.337^{*}$ & 0.025 \\
\hline ALP & $0.706^{*}$ & $<0.001$ & -0.067 & 0.667 & $0.405^{*}$ & 0.006 & $0.409^{*}$ & 0.006 & $0.416^{*}$ & 0.015 \\
\hline PT & $-0.357^{*}$ & 0.017 & 0.003 & 0.983 & $-0.376^{*}$ & 0.012 & $-0.336^{*}$ & 0.026 & $-0.315^{*}$ & 0.048 \\
\hline Bcl-w (RQ) & $-0.542^{*}$ & $<0.001$ & 0.083 & 0.592 & $-0.309^{*}$ & 0.041 & -0.286 & 0.060 & -0.123 & 0.425 \\
\hline miR-122 (RQ) & 1.000 & - & -0.241 & 0.115 & $0.465^{*}$ & 0.001 & $0.579^{*}$ & $<0.001$ & $0.356^{*}$ & 0.018 \\
\hline AFP & -0.241 & 0.115 & 1.000 & - & -0.271 & 0.075 & 0.041 & 0.790 & 0.030 & 0.847 \\
\hline Total viremia & $0.465^{*}$ & 0.001 & -0.271 & 0.075 & 1.000 & - & $0.566^{*}$ & $<0.001$ & 0.163 & 0.291 \\
\hline Fibronectin & $0.579^{*}$ & $<0.001$ & 0.041 & 0.790 & $0.566^{*}$ & $<0.001$ & 1.000 & - & $0.299^{*}$ & 0.049 \\
\hline
\end{tabular}

AFP: Alpha-fetoprotein, AST: Aspartate aminotransferase, ALT: Alanine aminotransferase. PT: Prothrombin time, ALP: Alkaline phosphatase, $\mathrm{P}$ is considered significant when $\mathrm{P} \leq 0.05$ 


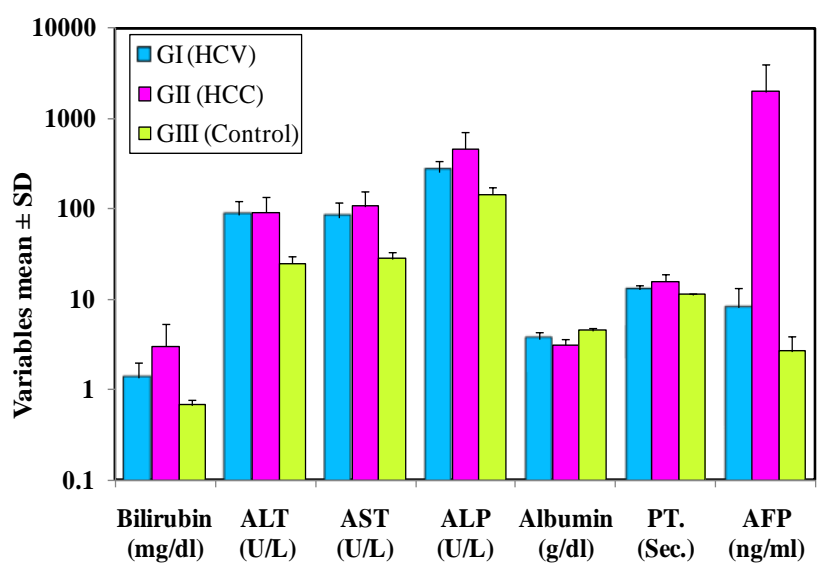

Fig. 1 Comparison of mean values of liver function tests and AFP among

different studied groups

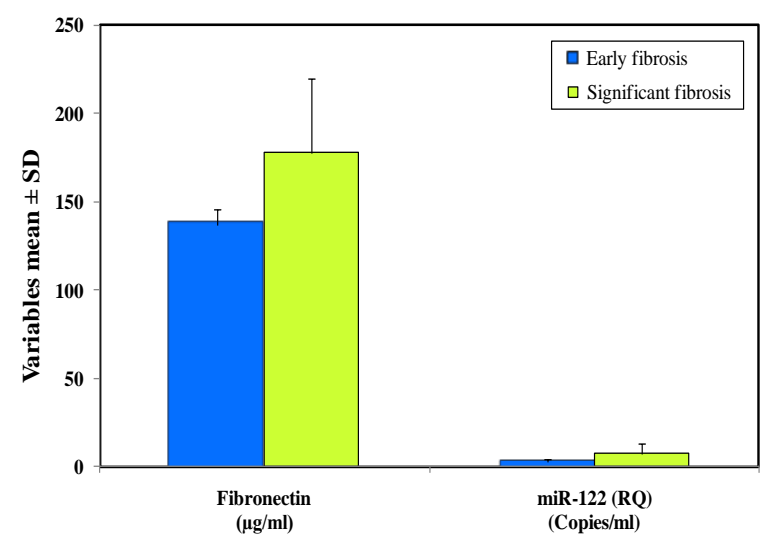

Fig. 3 Comparison of mean values of FN and miR-122 among early fibrosis group and significant fibrosis group

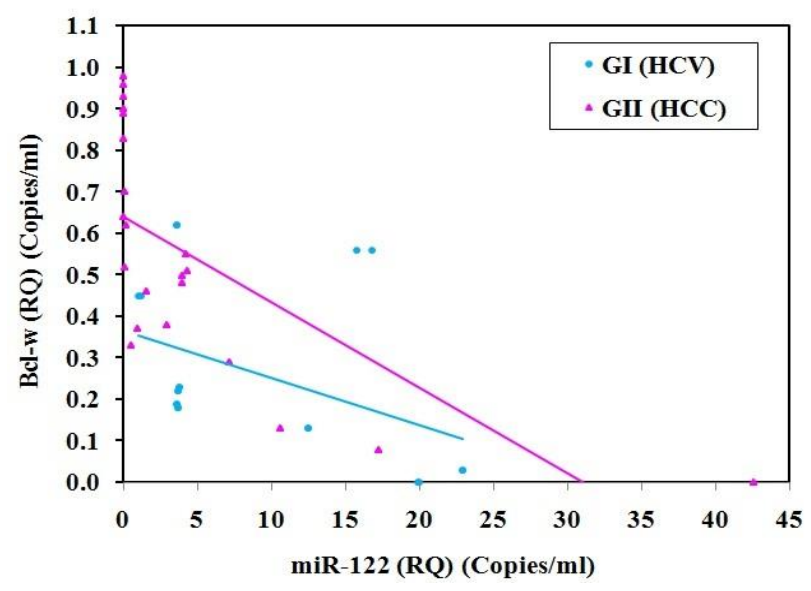

Fig. 5 Correlation between miR-122 and Bcl-w in HCV and HCC groups $(r=-.585, p=0.007)$ and $(r=-0.542$, $\mathrm{p}=<0.001$ ) respectively

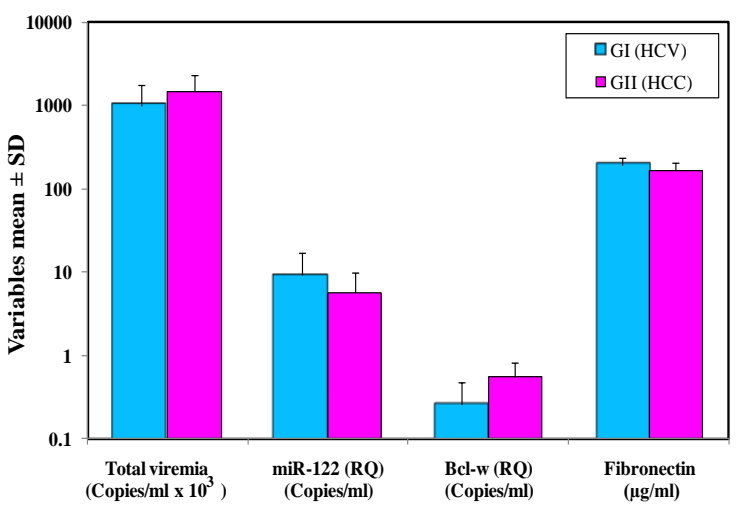

Fig. 2 Comparison of mean values of total viremia, miR-122, Bcl-w and FN among HCV group and HCC group

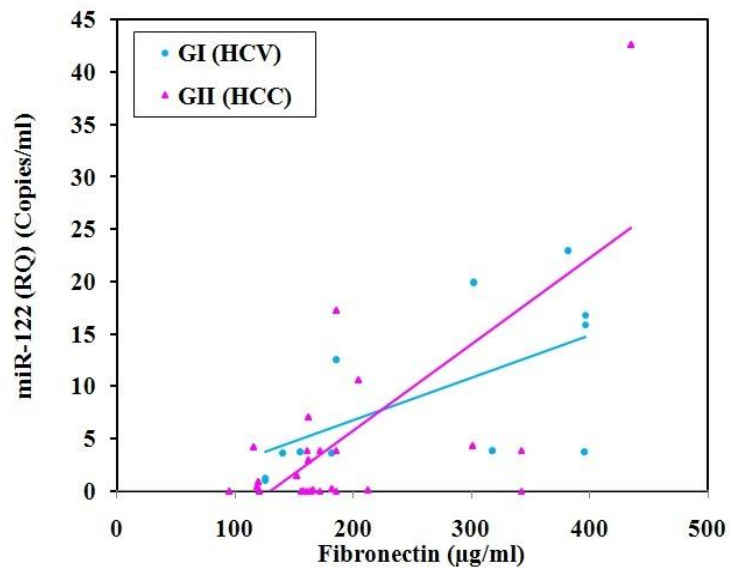

Fig. 4 Correlation between miR-122 (RQ) anc Fibronectin in $\mathrm{HCV}$ and $\mathrm{HCC}$ groups $(\mathrm{r}=0.669$ $\mathrm{p}=0.001)$ and $(\mathrm{r}=0.579, \mathrm{p}=<0.001)$ respectively

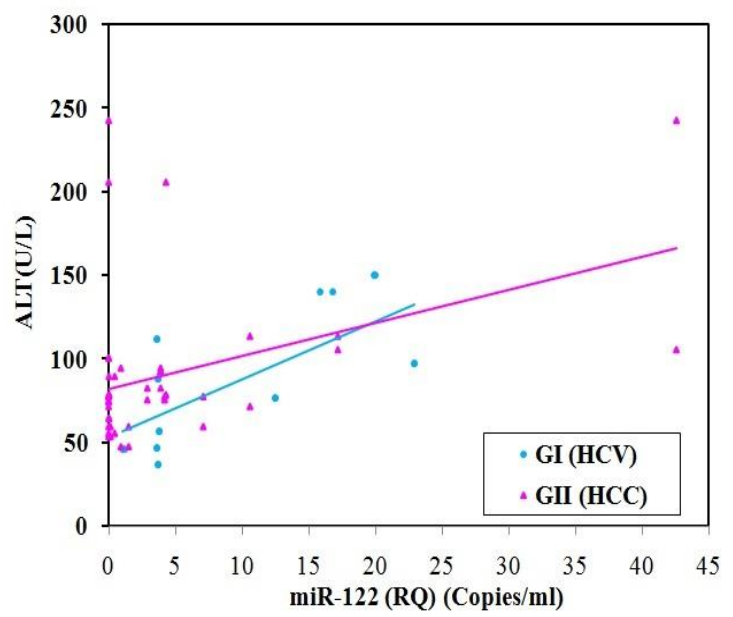

Fig. 6 Correlation between miR-122 and ALT in HCV and HCC groups ( $r=0.603, p=0.005)$ and $(r=0.424, p=0.004)$ respectively 


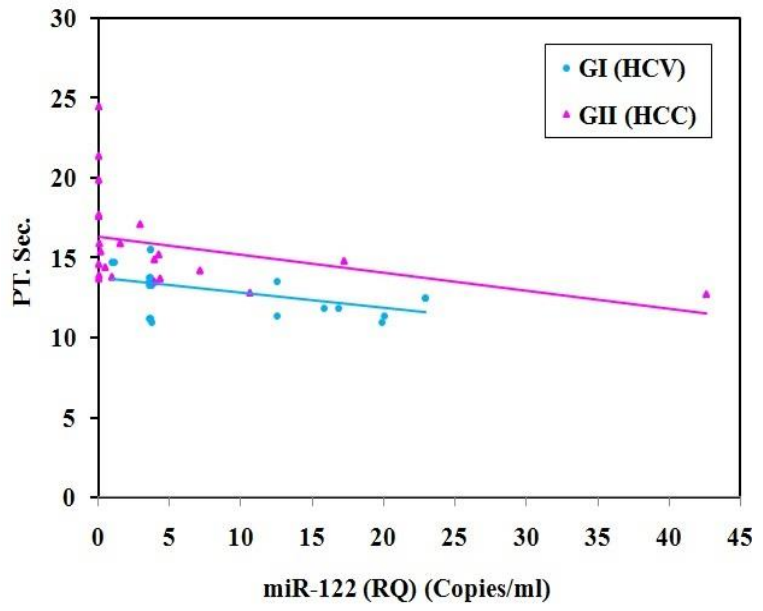

Fig. 7 Correlation between miR-122 and PT in HCV and H groups $(r=-0.499, p=, 0.025)$ and $(r=-0.357, p=0.017)$ respectively

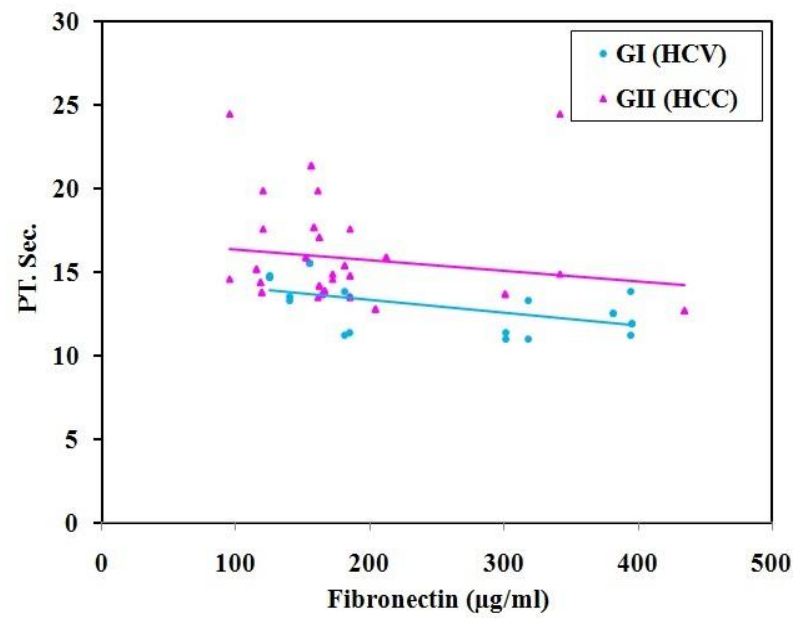

Fig. 9 Correlation between Fibronectin and PT in HCV and HCC groups

$(r=-0513, p=0.021)$ and $(r=-0.336, p=0.026)$ respectively

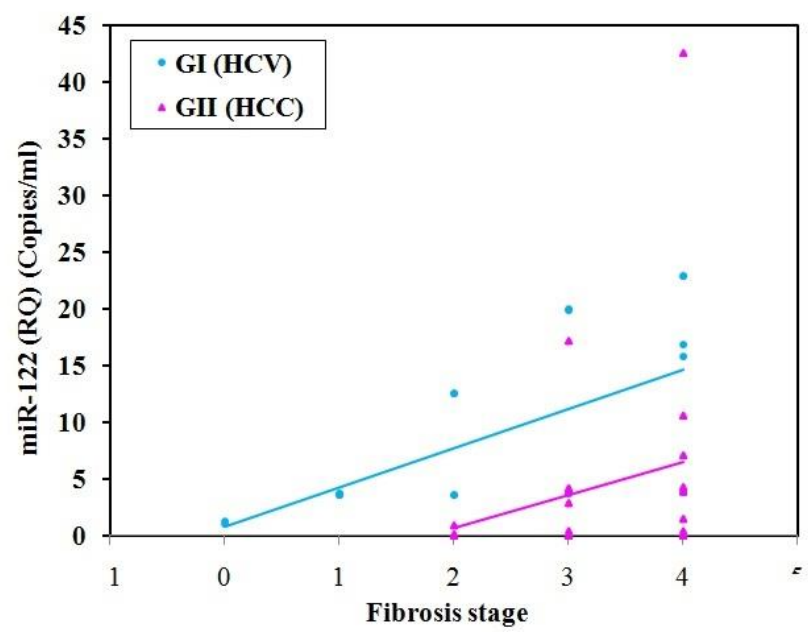

Fig. 11 Correlation between miR-122 and Fibrosis stage in HCV and HCC groups $(r=0.778, p=, 0.001)$ and $(r=$ $0.356, p=0.018$ ) respectively

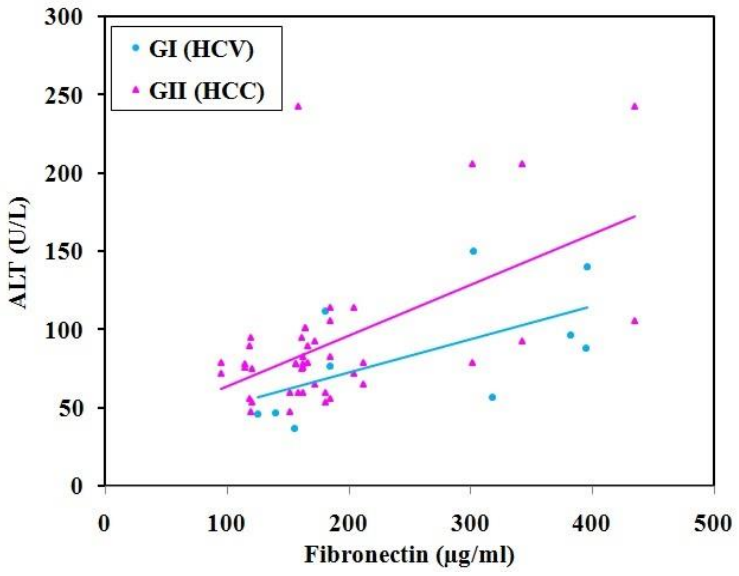

Fig. 8 Correlation between Fibronectin and ALT in HCV and HCC groups $(r=0.612, p=0.004)$ and $(r=0.492, p=0.001)$ respectively

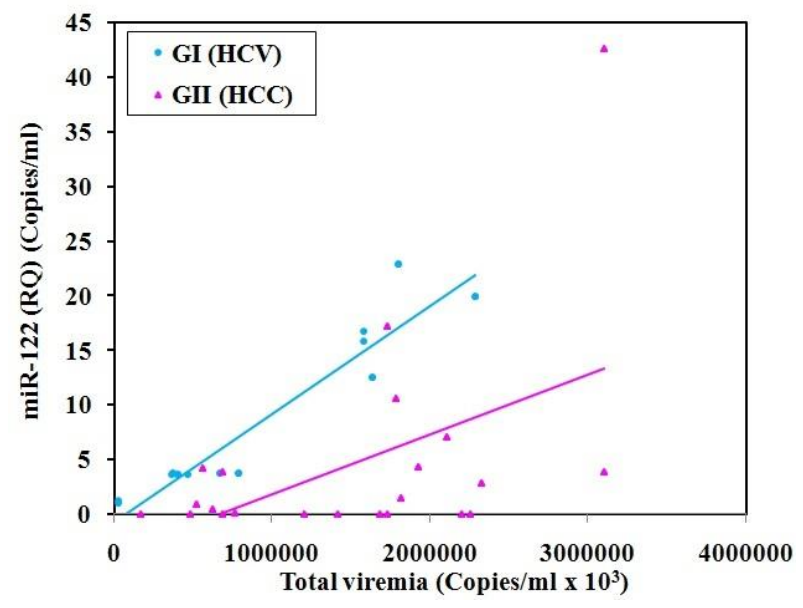

Fig. 10 Correlation between miR-122 and total viremia in HCV and HCC groups $(r=0.913, p=$ $<0.001)$ and $(r=0.465, p=0.001)$ respectively

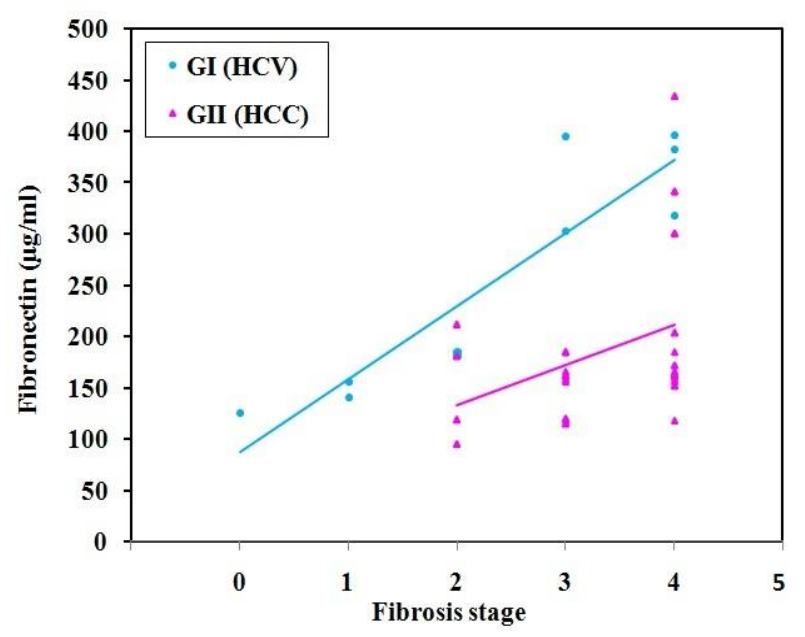

Fig. 12 Correlation between Fibronectin and Fibrosis stage in HCV and HCC groups $(r=0.885$, $\mathrm{p}=, 0.001)$ and $(\mathrm{r}=0.299, \mathrm{p}=0.049)$ respectively 
ROC curve analysis was designed for miR-122 and $\mathrm{FN}$ in early fibrotic patients against patients with significant fibrosis. Roc curve was performed as cut off for disease progression.

The results showed that the cut off for FN was 140 $\mu \mathrm{g} / \mathrm{ml}$; at sensitivity $79.31 \%$ and specificity $66.67 \%$, while the sensitivity and specificity for miR-122 were $55.17 \%$ and $83.33 \%$, respectively. The combined use of $\mathrm{FN}(79.31 \%)$ as well as miR-122 $(55.17 \%)$ achieved the highest sensitivity $(80.62 \%)$ making them as useful tool for screening patients with significant fibrosis. The overall combined sensitivity; specificity, Positive Predictive Value (PPV) and negative predictive value (NPV) are represented in (figure 14), and showed in (table 7).

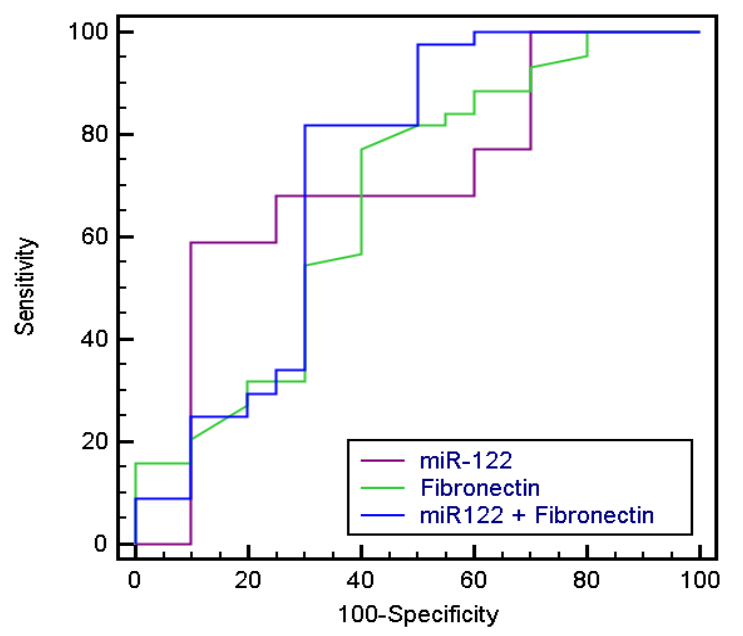

Fig. 14 Different diagnostic values of miR-122 and FN obtained from Roc curve

\begin{tabular}{|c|c|c|c|c|c|c|}
\hline $\begin{array}{c}\text { Biochemical } \\
\text { parameter }\end{array}$ & $\begin{array}{c}\text { ROC } \\
\text { Area } \\
\text { under the } \\
\text { curve }\end{array}$ & Sig & $\begin{array}{c}\text { Youden's } \\
\text { index }\end{array}$ & Sensitivity & Specificity & $\begin{array}{c}\text { Cut off } \\
\text { value }\end{array}$ \\
\hline miR-122 & $0.705^{*}$ & 0.009 & 0.491 & 63.64 & 75.0 & $\leq 3.85$ \\
\hline Fibronectin & $0.673^{*}$ & 0.028 & 0.373 & 77.27 & 60.0 & $\leq 199$ \\
\hline $\begin{array}{c}\text { miR122 + } \\
\text { Fibronectin }\end{array}$ & $0.727^{\star}$ & 0.004 & 0.633 & 84.09 & 70.0 & $\leq 3.85 / \leq 199$ \\
\hline \multicolumn{7}{|c|}{ Youden index = (Specificity + Sensitivity) -1 } \\
\hline
\end{tabular}

Table 6: Frequency distribution and risk estimate at miR-122 and FN cut off values in HCV infected patients and HCC patients

\begin{tabular}{|c|c|c|c|c|c|c|c|c|}
\hline Parameter & Group & $\begin{array}{l}\text { Cut off } \\
\text { value }\end{array}$ & PPV & NPV & $X^{2}$ & OR & $95 \% \mathrm{Cl}$ & $\mathbf{P}$ \\
\hline miR-122 & $\begin{array}{l}\mathrm{HCV} \\
\mathrm{HCC}\end{array}$ & $\leq 3.85$ & 84.85 & 48.39 & $8.218^{*}$ & 5.250 & $\begin{array}{l}1.607- \\
17.153\end{array}$ & $0.007^{\star}$ \\
\hline Fibronectin & $\begin{array}{l}\mathrm{HCV} \\
\mathrm{HCC}\end{array}$ & $\leq 199$ & 80.95 & 54.55 & $8.468^{*}$ & 5.100 & $\begin{array}{l}1.633- \\
15.931 \\
\end{array}$ & $0.005^{*}$ \\
\hline $\begin{array}{c}\text { miR - } 122 \\
\text { +Fibronectin }\end{array}$ & $\begin{array}{l}\text { HCV } \\
\text { HCC }\end{array}$ & $\leq 3.85 / \leq 199$ & 80.95 & 54.55 & $8.192^{*}$ & 5.286 & $\begin{array}{l}1.605- \\
17.410\end{array}$ & $0.007^{*}$ \\
\hline
\end{tabular}

Special volume for the first International Conference of Genetic Engineering and Biotechnology,
The areas under the $(\mathrm{ROC})$ curve of fibronectin and miR-122 for discriminating patients with significant fibrosis from those with early fibrosis livers and its $p$ values were 0.819 and 0.690 $(P=0.030, P=0.099)$, respectively. While the combined use of miR-122 and FN presented a significant urea under the curve of 0.828 and $P=0.024$. As represented in (figure 14), and showed in (table 7). (Table 7) represented the risk estimate at a relative miR-122 and FN cut off values $3.7 / 140$, after calculating the positive and negative predictive values. A significantly elevated relative risk by 10.26 folds more for developing liver fibrosis after HCV infection.

Fig. 13 Different diagnostic values of miR-122 and FN obtained from Roc curve

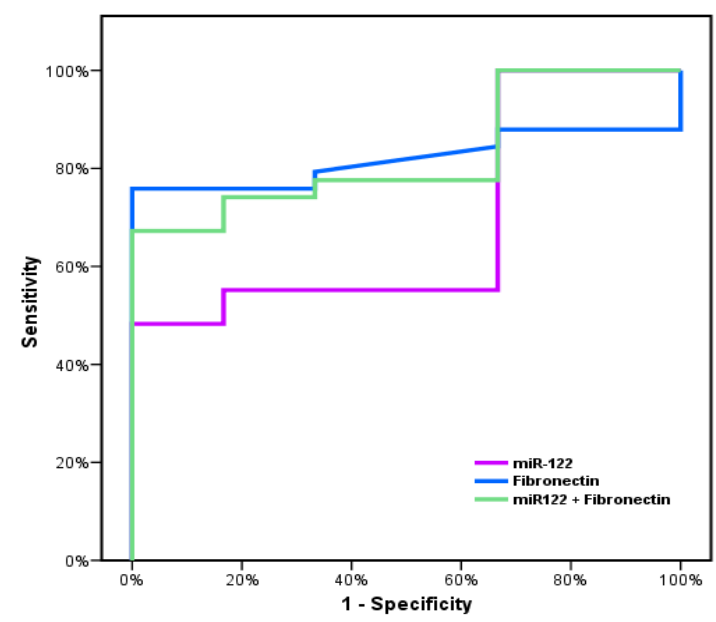


$\mathrm{X}^{2}$ : obtained by chi-square test. PPV: positive predictive value, NPV: negative predictive value, $\mathrm{P}$ : is considered significant $\leq 0.05$, OR: Odds Ratio, $95 \% \mathrm{Cl}$ : $95 \%$ confidence interval.

\begin{tabular}{|c|c|c|c|c|c|c|}
\hline $\begin{array}{c}\text { Biochemical } \\
\text { parameter }\end{array}$ & $\begin{array}{c}\text { ROC } \\
\text { Area } \\
\text { under the } \\
\text { curve }\end{array}$ & Sig & $\begin{array}{c}\text { Youden's } \\
\text { index }\end{array}$ & Sensitivity & Specificity & $\begin{array}{c}\text { Cut off } \\
\text { value }\end{array}$ \\
\hline miR-122 & 0.690 & 0.128 & 0.483 & 55.17 & 83.33 & $>3.7$ \\
\hline Fibronectin & $0.819^{*}$ & 0.011 & 0.759 & 79.31 & 66.67 & $>140$ \\
\hline $\begin{array}{c}\text { miR122 + } \\
\text { Fibronectin }\end{array}$ & $0.828^{*}$ & 0.009 & 0.772 & 80.62 & 77.23 & $>3.7 />140$ \\
\hline \multicolumn{7}{|c|}{ Youden index = (Specificity + Sensitivity) -1 } \\
\hline
\end{tabular}

Table 7: Frequency distribution and risk estimate at miR-122 and FN cut off values in early fibrotic patients and significant fibrotic patients

\begin{tabular}{|c|c|c|c|c|c|c|c|c|}
\hline Parameter & Group & $\begin{array}{l}\text { Cut off } \\
\text { value }\end{array}$ & PPV & NPV & $X^{2}$ & OR & $95 \% \mathrm{Cl}$ & $\mathbf{P}$ \\
\hline \multirow{2}{*}{ miR-122 } & F0-F1 & \multirow{2}{*}{$>3.7$} & \multirow{2}{*}{96.97} & \multirow{2}{*}{16.13} & \multirow{2}{*}{3.228} & \multirow{2}{*}{6.154} & \multirow{2}{*}{$0.68-56.014$} & \multirow[t]{2}{*}{0.099} \\
\hline & F2-F4 & & & & & & & \\
\hline \multirow{2}{*}{ Fibronectin } & F0-F1 & \multirow{2}{*}{$>140$} & \multirow{2}{*}{95.0} & \multirow{2}{*}{25.0} & \multirow{2}{*}{$6.130^{\star}$} & \multirow{2}{*}{7.667} & \multirow{2}{*}{$1.25-46.958$} & \multirow{2}{*}{$0.030^{\circ}$} \\
\hline & F2-F4 & & & & & & & \\
\hline \multirow{2}{*}{$\begin{array}{c}\text { miR- } 122 \\
\text { +Fibronectin }\end{array}$} & F0-F1 & \multirow{2}{*}{$>3.7 />140$} & \multirow[b]{2}{*}{97.50} & \multirow{2}{*}{25.83} & \multirow{2}{*}{$5.934^{*}$} & \multirow{2}{*}{10.26} & \multirow{2}{*}{$1.12-94.114$} & \multirow{2}{*}{0.024} \\
\hline & F2-F4 & & & & & & & \\
\hline
\end{tabular}

$\mathrm{X}^{2}$ : obtained by chi-square test. PPV: positive predictive value, NPV: negative predictive value, P: is considered significant $\leq 0.05$, OR: Odds Ratio, $95 \% \mathrm{Cl}$ : $95 \%$ confidence interval.

Chronic HCV infection causes normally quiescent hepatocytes to divide repeatedly, leading to fibrosis, cirrhosis and occasionally progression to hepatocellular carcinoma (HCC) (Chang et al., 2000) .Liver cirrhosis is the most common complication of chronic HCV infection. Once cirrhosis is established, the risk of developing HCC is increased (Davila et al., 2004). AFP is a serum glycoprotein that was first recognized as a marker for HCC more than 40 years ago and has been described to detect preclinical HCC. The fetal yolk sac and fetal liver generate high levels of AFP, which decline to $<10 \mathrm{ng} / \mathrm{ml}$ within 300 days of birth (Kashyap et al., 2001) .Our results showed that AFP serum levels were significantly increased in all patients groups as compared to control group, its levels in HCC patients was significantly higher than in HCV patients without HCC. This finding is in agreement with (yang et al., 2005) and (Scholz et al., 2007). A study from Thailand found that HCC patients with AFP $>400 \mathrm{ng} / \mathrm{ml}$ tend to have greater size, bilobar involvement, portal vein thrombosis and decreased survival (Tangkijvanich et al. , 2000).Liver diseases other than HCC are accompanied by high levels of AFP. In addition, a significant proportion of $\mathrm{HCC}$ patients did not have an elevated AFP. Nontumors liver cells also abundantly express AFP mRNA. AFP represents liver cell-specific, not tumor specific markers (Frank et al., 2012). Nowadays, the search for noninvasive biomarkers for the diagnosis of diseases has become a rapidly growing area of clinical research. Micro RNA expression has been studied at cellular level and in tissues in patients with HCC. MicroRNAs (miRNAs) are small non-coding RNAs that inhibit messenger RNAs (mRNAs) by binding to their $3^{\prime}$ untranslated regions (UTRs). miRNA are predicted to repress up to $1 / 2$ of all human genes post-transcriptionally through translational arrest and/or mRNA degradation (Friedman et al. , 2009). MiRNAs regulate diverse functions, including cell proliferation and apoptosis, and they are dysregulated in cancers, including HCC (Murakami et al., 2006) .Micro RNAs are important mediators of HBV and HCV infection as well as liver disease progression, and therefore could be potential therapeutic target molecules ( Ura et al. , 2009). Various microRNAs are now being investigated in hepatitis $C$ virus infection with the most popular one being micro RNA-122, micro RNA-122 is the most abundant micro RNA 
in the liver (Jopling et al., 2005) where it has many important biological roles, such as in fatty acid metabolism, and circadian rhythms under normal conditions (Chang et al. , 2008) .Micro RNA-122 was found to interact with HCV RNA enhancing its replication (Gatfield et al., 2009) .It was suggested that miR-122 triggers HCV replication by posttranscriptional repression of heme oxygenase enzyme (Shan et al. , 2007). Blockage of miRNA -122 has been considered as a therapeutic approach against chronic hepatitis $C$ (Janssen et al., 2013). Since progression of fibrosis varies in patients, distinguishing between rapid from slow fibrosis would allow a better tailoring of the treatment (Poynard et al., 2003).To date, this is best achieved by follow-up liver biopsies or repeat measurement of liver stiffness. Both methods have their limitations. Biopsy due to its invasiveness may lead to relevant complications (Bedossa et al. , 2003) , while liver stiffness measurement has the drawback of questionable or lacking results in patients with ascites, obesity, cholestasis, or hepatic inflammation and a considerable overlap in patients with low or moderate fibrosis (Koch et al. , 2011). Serological biomarkers could offer a noninvasive alternative for assessment of fibrosis in chronic liver disease. Yet, their diagnostic accuracy has still limitations. The present work aimed to assess whether serum levels of miR-122 and FN can be used not only as a novel non invasive biomarker for liver injury and liver function capacity but also can be used to discriminate patients with HCC from those with $\mathrm{HCV}$. The present work also was carried out to examine whether circulating levels of miR-122 and FN correlate with liver disease severity in HCV patients with and without HCC, and can potentially serve as circulating biomarkers for liver disease stage assessment. The current study revealed a significant positive correlation between miR-122 expression levels and fibrosis stage in HCV and HCC groups $(p=<0.001,0.018$ respectively). This finding is in agreement with (Cermelli et al., 2011) who reported that miRNA122 and miRNA-34a levels positively correlated with disease severity and stated that serum levels of miRNA-34a and miRNA-122 may represent novel noninvasive biomarkers for diagnosis of histological disease severity in patients with $\mathrm{CHC}$ or NAFLD. While, another study by (Trebicka et al., 2013) concluded that circulating miR-122 levels correlated negatively with increasing stages of fibrosis. Bihrer et al., 2011 reported that sera from patients with $\mathrm{CHC}$ contained higher levels of
miRNA -122 than sera from healthy controls. They add that the serum level of miRNA -122 strongly correlates with serum ALT levels and with necroinflammatory activity in patients with $\mathrm{CHC}$, but not with fibrosis stage and functional capacity of the liver. The conflict here is that in the present study, serum miR-122 levels correlates with fibrosis stage and liver function capacity. Moreover, in our study Micro RNA-122 expression level were further elevated in patients with HCC. This finding is in agreement of (Varnholt et al. , 2008) who examined the microRNA expression profiles in a large set of 52 human primary liver tumors consisting of premalignant dysplastic liver nodules and hepatocellular carcinomas by quantitative real-time polymerase chain reaction. All patients were infected with hepatitis $C$, and most had liver cirrhosis. They stated that miRNA122, miRNA100, and miRNA -10 were over expressed whereas miR-198 and miR-145 were up to 5-fold down-regulated in hepatic tumors compared to normal liver parenchyma. They concluded that miR-122 was strongly up-regulated in dysplastic and malignant liver nodules in the large sample set, and they suggested that miRNA-122 might down regulate target mRNA of undetermined tumor suppressor genes and thus lead to increased tumor growth. A study by (Zhang et al., 2010) reported that circulating miR122 levels were elevated in patients with chronic hepatitis $B$ viral (HBV) infection, and correlate with liver histologic stage, inflammation grades and ALT activity. Another study by (Xu et al., 2011) reported that serum miR-122 levels were also higher in patients with Chronic HBV infection than in patients with HCC. We are reporting here similar results for miR-122 in patients with HCV infection with and without HCC suggesting that the increase in circulating levels of miR-122 is common to chronic liver disease of all etiologies. A Study by (Köberle et al., 2013); In Germany reported that serum miR-122 and miR-1 levels did not significantly differ between patients with and without HCC. The conflict here is that in our study serum miR-122 expression levels differ significantly between patients with $\mathrm{HCV}$ and patients with $\mathrm{HCC}$ associated with $\mathrm{HCV}$ $(\mathrm{P}=0.025)$. Our data from patient groups (HCV and $\mathrm{HCC}$ ) showed that miR-122 expression levels were positively correlated with ALT, AST, and ALP; i.e. parameters of liver cell damage; and negatively correlated with prothrombin time and albumin, indicators of liver functions. These results were in agreement with (Köberle et al., 
2013), who reported that; serum miRNA -122 correlated with clinical chemistry parameters of hepatic necroinflammation, liver function and synthetic capacity. The study depicted the correlation of serum miR-122 level with HCV viral load, ALT, and AST activity in patient's sera. Besides, viral RNA also showed a positive correlation with ALT and AST activity; While HCV viral RNA is significantly associated with miR- 122 and likewise miR-122 showed a positive correlation with ALT and AST activity. These observations further enhance the diagnostic importance ofmiR-122. Apparently, miR-122 is quite stable and more sensitive in the serum whereas ALT and AST enzymes are comparatively less stable (Mc Donald et al., 2011). Moreover, quantification of viral RNA is quite expensive and time consuming procedure. Hence, these findings authenticate miR-122 as a promising biomolecule to investigate $\mathrm{HCV}$ infection and monitor liver dysfunctions. Contrary to our findings of miR-122 positively correlate with total viremia, in HCV and HCC groups $(P=$ $<0.001,0.001$ respectively), other authors have reported that in $\mathrm{CHC}$ patients, miR-122 levels correlated with fibrosis stage and inflammation activity but didn't correlate with HCV viral load (Poynard et al., 2003). The only validated target gene of miR-122, a liver-specific miRNA that is down-regulated in HCC, is CCNG1. Here, we report the modulating effects of miR-122 on Bcl-w expression. The results of $\mathrm{Bcl}-\mathrm{w}$ targeting by miR122 may have implications in the pathogenesis of $\mathrm{HCC}$. Our data reported that up-regulation of miR122 expression in HCV patients with and without $\mathrm{HCC}$ was accompanied by down-regulation of Bcl$w$ expression level in both groups but the down regulation in HCV group without HCC was significantly higher than HCC group $(P=<0.001)$.Our results were in agreement with (Lin et al., 2008); In Taiwan who suggested that decreased miR-122 expression helps cells evade cell death, a cardinal feature of cancer cells. Therefore, the reduced levels of miR-122 in HCC group enhance anti-apoptotic activity through an increase in the Bcl-w/Bax ratio. Also our results were in agreement with (Kumar et al., 2012) who reported that, miR-122 was frequently downregulated in $\mathrm{HCC}$; in contrast, its target genes cyclin G1 and Bcl-w was up-regulated. Fibronectin plays crucial roles in various cellular functions, including cell adhesion, migration, proliferation and differentiation (Hynes et al., 1980).According to previous reports, plasma fibronectin is mainly produced by hepatocytes and cellular fibronectin in liver is produced, at least in part, by endothelial cells, fat-storing cells and to a lesser extent, by hepatocytes. It has also been mentioned that fibronectin plays important roles in hepatic fibrogenesis (Matsui et al., 1997) .There is a need for accurate biochemical markers to aid in early diagnosis of liver fibrosis. Several connective tissue substances have been studied as noninvasive markers for liver cirrhosis, e.g., hyaluronic acid, type III procollagen $\mathrm{N}$-terminal peptide, collagen type I, II, IV, laminin and fibronectin and have been proposed to represent hepatic fibrosis, focusing particularly on the diagnosis of hepatic cirrhosis (Fortunato et al. , 2001). The current study analyzed the FN concentrations in the plasma of $20 \mathrm{HCV}$ infected patients, $44 \mathrm{HCC}$ patients associated with $\mathrm{HCV}$ and in 20 healthy controls. These results showed that serum FN levels were significantly increased in all patient groups when compared to the control group $(P=<0.001)$. These results were in agreement with those obtained by (Mosa et al., 2007; Attallah et al., 2007) who reported that serum FN was significantly higher in fibrotic patients when compared to the control group. Similar to Previous study in patients with chronic HCV (Attallah et al., 2007), we found significant positive correlation between serum $\mathrm{FN}$ levels and ALT, AST, ALP, fibrosis stage and significant negative correlation with Albumin, prothrombin concentration. The level of plasma fibronectin increased in our fibrotic patients with $\mathrm{HCV}$ infection (with and without HCC) agrees with (Fortunato et al., 2001). Increased amounts of fibronectin are significant in the development of early liver fibrosis and fibronectin may act as a chemotactic factor for collagen producing cells and as a skeleton for the new collagen formation (Junge et al., 1988). A contradictory study by (Erturk et al., 2014) Postulated that serum FN levels were lower in both acute and chronic hepatitis patients, and an inverse relationship between serum FN and serum AST, ALT, and GGT levels was found. A decrease in serum FN levels may indicate hepatitis severity as AST and ALT represent hepatocyte damage. Another Study by (Kandemir et al., 2004) evaluated serum FN levels and liver enzymes AST and ALT in patients with chronic viral hepatitis $B$ and $C$. They found that serum FN levels were significantly lower and AST and ALT levels were higher in patients than controls. They also found a negative, but nonsignificant correlation between serum $\mathrm{FN}$ and, 
ALT and AST levels. In the present study, we observed lower levels of miR-122 in patients with more advanced fibrosis (F4), indicating that reduced serum miR- 122 is most likely the result of reduced release from heptocytes. This indicates that in patients with severe liver fibrosis, the miR-122 serum levels might be a marker for hepatic functional capacity, whereas at earlier stages of liver disease, the serum miR-122 levels is mainly an indicator of necroinflammatory activity and cell death in the liver. As release from damaged hepatocytes might be the major source of hepatocyte-derived miRs (Wang et al., 2010). It is conceivable that in patients with severe fibrosis who lost a big proportion of hepatocytes and thus have less functional hepatic capacity, the release of miRs upon damage might be lower than in patients with higher amounts of healthy liver tissue. We also observed lower levels of FN in patients with severe fibrosis (F4), the reason for this may be due to the same reason which causes depletion of miR-122 in patients with more advanced fibrosis. Our results indicated that there was not a significant difference in miR-122 level between patients with early fibrosis and patients with significant fibrosis $(p=0.152)$. Contrary to our results, (Cermelli et al., 2011) reported that serum miR-122 levels were significantly increased in the markers for detecting the progression of hepatocellular carcinoma after HCV infection. In addition, in the present study, the diagnostic performance of the Roc curve revealed that; the combined use of miR-122 (55.17\%) and FN (79.31) achieved the highest sensitivity $(80.62 \%)$ for screening patients with significant fibrosis. The area under the Roc curve of combined miR-122 and $\mathrm{FN}$ for discriminating patients with significant fibrosis from those with early fibrosis and its $P$ value were 0.828 and 0.024 , respectively. This finding makes miR-122 besides $\mathrm{FN}$; are good markers for detecting the progression of liver fibrosis after HCV infection. Conclusion: This study shed light on the functions of miR-122 which may act as an endogenous apoptosis regulator and thus negatively regulates tumourigensis. Also this study concluded that miR-122 and FN can be used as novel biomarkers for liver injury and may be used to discriminate patients with HCC from $\mathrm{HCV}$. Overall, the prospect of using miR-122 and $\mathrm{FN}$ as prognostic markers is of interest. Larger patient cohorts with differential fibrosis states will have to be analyzed to further test the utility of circulating miR-122 and FN as biomarkers for
CHC-advanced group compared to the $\mathrm{CHC}$-early group. Moreover, in our study there was a significant difference in plasma fibronectin levels between Patients with significant fibrosis compared to those with early fibrosis $(p=0.011)$. These results were in some way in a good agreement with (Attallah et al., 2007) who reported that there were a significant difference in fibronectin level between patients with fibrotic liver (F1-F3) compared to those with non-fibrotic liver (F0). The current study reported that although miR-122 expression levels in HCV group were significantly elevated than HCC group $(p=0.025)$, its levels were higher in patients with significant fibrosis when compared to those with early fibrosis, this may be due to that $70 \%$ of HCV patients were included in a group of patients with significant fibrosis. The diagnostic performance of the Roc curve, in the present study, by examining the different studied parameters revealed that; the combined use of miR-122 (63.64\%) and FN (77.27\%) achieved the highest sensitivity $(84.9 \%)$ for screening of HCC patients. The area under the Roc curve of combined miR-122 and FN for discriminating $\mathrm{HCC}$ from HCV patients and its $\mathrm{P}$ value were 0.727 and 0.007 , respectively. This finding makes miR-122 besides $\mathrm{FN}$; are good

detection or monitoring of hepatocellular carcinoma and liver fibrosis.

\section{REFERENCES}

A. Krek, D. Grun, M.N. Poy, R. Wolf, L. Rosenberg, E.J. Epstein, P. MacMenamin, I. da Piedade, K.C. Gunsalus, M. Stoffel, N. Rajewsky, Combinatorial microRNA target predictions, Nat. Genet. 2005; 37: 495-500.

Attallah, A. M., Zahran, F., Ismail, H., et al. Immunochemical identification and detection of serum fibronectin in liver fibrosis patients with chronic hepatitis C. Journal of Immunoassay and Immunochemistry 2007; 28(4):331-342.

Bataller R, Brenner DA. Liver fibrosis. J Clin Invest 2005; 115:209-218.

Bedossa P, Dargere D, Paradis V. Sampling variability of liver fibrosis in chronic hepatitis C. Hepatology 2003;38:1449-1457.

Bedossa P, Dargere D, Paradis V. Sampling variability of liver fibrosis in chronic hepatitis C. Hepatology 2003; 38:1449-1457.

Befeler AS, Di Bisceglie AM .Hepatocellular carcinoma: diagnosis and treatment. Gastroenterology 2002; 122:1609-19. 
Bihrer V, Friedrich-Rust M, Kronenberger B, Forestier N, Haupenthal J, et al. .Serum miR122 as a biomarker of necroinflammation in patients with chronic hepatitis C virus infection. Am J Gastroenterol 2011; 106(9):1663-9.

Borchert GM, Lanier W, Davidson BL .RNA polymerase III transcribes human microRNAs. Nat Struct Mol Biol, 2006; 13(12), 1097-101.

Bosch FX, Ribes J, Diaz M, Cleries R. Primary liver cancer: worldwide incidence and trends.Gastroenterology 2004; 127: S5-S16.

Cermelli S, Ruggieri A, Marrero JA, loannou GN, Beretta L. Circulating MicroRNAs in Patients with Chronic Hepatitis C and Non-Alcoholic Fatty Liver Disease. PLoS ONE 2011; (8):e23937.doi:10.1371/journal. pone.

Chang J, Guo JT, Jiang D, Guo H, Taylor JM et al. Liver-specific microRNA miR-122 enhances the replication of hepatitis $C$ virus in non hepatic cells J. Virol 2008; 82(16): 8215-8223.

Chang M, Marquardt AP, Wood BL, et al. In situ distribution of hepatitis $C$ virus replicativeintermediate RNA in hepatic tissue and its correlation with liver disease. J Virol. 2000; 74:944-955.

Chen, C., Ridzon, D.A., Broomer, A.J., Zhou, Z., Lee, D.H., Nguyen, J.T., Barbisin, M., Xu, N.L., Mahuvakar, V.R., Andersen, M.R., Lao, K.Q., Livak, K.J. and Guegler, K.J. Real-time quantification of microRNAs by stem-loop RT-PCR. Nucleic Acids Res, 2005; 33(20) e179.

Czepiel J, Biesiada G, Mach T.Viral hepatitis C; Pol Arch Med Wewn. 2008; 118(12):734-40.

Davila J A, Morgan RO, and Shaiby Y . Hepatitis C infection and the increasing incidence of hepatocellular carcinoma: a populationbased study. Gastroenterology 2004; 127:1372-1376.

El-Zayadi AR, Badran HM, Barakat EM, Attia MelD, Shawky S, Mohamed MK, Selim O, Saeid A. Hepatocellular carcinoma in Egypt: a single center study over a decade. World J Gastroenterol 2005; 11:5193 5198.

Erturk A.,Cure E., Ozkurt Z., Parlak E., et al. Serum Fibronectin levels in Acute and Chronic Viral Hepatitis Patients. Malays J Med Sci. 2014; 21(1):29-36.

Fortunato, G., Castaldo, G., Oriani, G., et al. .Multivariate discriminate function based on six biochemical markers in blood can predict the cirrhotic evolution of chronic hepatitis. Clinical Chemistry 2001; 47(9):1696-1700.

Frank C. Circulating tumor cells measurements in hepatocellular carcinoma. .Int $\mathrm{J}$ Hepatol http 2012;//dx.doi.org/10.1155/2012/68480.

Friedman RC, Farh KK, Burge CB, Bartel DP. Most mammalian mRNAs are conserved targets of microRNAs. Genome Res. 2009; 9:92-105.

Friedman RC, Farh KK, Burge CB, Bartel DP. Most mammalian mRNAs are conserved targets of microRNAs. Genome Res. 2009; 9:92-105.

Garzon R, Calin GA, Croce CM. .MicroRNAs in Cancer. Annu Rev Med. 2009; 60:167-79.

Gatfield D, Le Martelot G, Vejnar CE, Gerlach D, et al Integration of microRNA miR-122 in hepatic circadian gene expression. Genes Dev2009; 23(11): 1313-1326.

Hilden J.,Glaziou P. Regret graphs-diagnostic uncertainty and Youden index ,Statistics in medicine 1996;15:969-86.

Hynes, R. O. The role of fibronectin in cellular behavior. Results and Problems in Cell Differentiation 1980; 11:112-123.

J. S.Mc Donald, D. Milosevic, H. V. Reddi, S. K. Grebe, and A. A. Schimnich. "Analysis of circulating microRNA: preanalytical and analytical challenges," Clinical Chemistry 2011; 57:833-840.

Janssen HL, Reesink HW, Lawitz EJ, Zeuzem S, Rodriguez-Torres M, et al. Treatment of HCV infection by targeting microRNA. N Engl J Med 2013; 368: 1685-1694. doi: 10.1056/nejmoa1209026.

Jopling, C. L., M. Yi, A. M. Lancaster, S. M. Lemon, and $P$. Sarnow. Modulation of hepatitis $C$ virus RNA abundance by a liverspecific micro RNA. Science 2005; 309:15771581.

Junge, J.; Horn, T.; Christoffersen, P. The occurrence and significance of fibronectin in livers from chronic alcoholics. An immunohistochemical study of early alcoholic liver injury. APMIS 1988; 96 (1), 56-61.

Kandemir O, Polat G, Sahin E, Bagdatoglu O, Camdeviren $\mathrm{H}$, Kaya A. Fibronectin levels in chronic viral hepatitis and response of this protein to interferontherapy. Hepatogastroenterol. 2004; 51(57):811-814.

Kashyap R, Join A, Nalesnik M, Carr B, Barnes J, Vargas $\mathrm{HE}$, et al. .Clinical significance of elevated alpha-fetoprotein in adults and children. Dig Dis Sci. 2001; 46:1709-13. 
Köberle V, Kronenberger B, Pleli T. Trojan J et al. Serum microRNA-1 and microRNA-122 are prognostic markers in patients with hepatocellular carcinoma European Journal of Cancer 2013; 49(16): 3442-3449.

Koch A, Horn A, Duckers H, Yagmur E, Sanson E, Bruensing $J$, et al. Increased liver stiffness denotes hepatic dysfunction and mortality risk in critically ill non-cirrhotic patients at a medical ICU. Crit Care 2011; 15:R266.

Kumar S, Chawla YK,Ghosh S,Chakraborti A. Over expression of MicroRNA -122 (MIR122) induces apoptosis by targeting cyclin G1 and Bcl-w genes in vitro.20 $0^{\text {th }}$ annual conference of INASL 2012; 29:140-148.

L. Gibson, S.P. Holmgreen, D.C. Huang, O. Bernard, N.G. Copeland, N.A. Jenkins, G.R. Sutherland, E. Baker, J.M. Adams, S. Cory, bcl-w, a novel member of the bcl-2 family, promotes cell survival, Oncogene 1996; 13: 665-675.

L. Gramantieri, M. Ferracin, F. Fornari, A. Veronese, S. Sabbioni, C.G. Liu, G.A. Calin, C. Giovannini, E. Ferrazzi, G.L. Grazi, C.M. Croce, L. Bolondi, M. Negrini, Cyclin G1 is a target of miR-122a, a microRNA frequently down-regulated in human hepatocellular carcinoma, Cancer Res. 2007 ; 67: 60926099.

Lin CJ,Gong H Y, Tseng H C, Wang W L, Wu J $\mathrm{L}$. MiR-122 targets an apoptotic gene, Bcl-w in human hepatocellular carcinoma cell lines

Biochem. And Biophys. Research communication 2008; 375:315-320.

Matsui, S., Takahashi, T., Oyanagi, Y., et al. Expression, localization and alternative splicing pattern of fibronectin messenger RNA in fibrotic human liver and hepatocellular carcinoma. Journal of Hepatology 1997; 27(5):843-853.

Morishima C, Morgan TR, Everhart JE, et al. HCV RNA detection by TMA during the hepatitis $\mathrm{C}$ antiviral long-term treatment against cirrhosis (Halt-C) trial. Hepatol, 2006; 44:360-7.

Mosa T. E., Khayyal A. A. ,Saad A., Abo-Zeid M, M. Evaluation of serum fibronectin and Interleukin -10 in Egyptian patients with combined viral hepatitis C and Schistosomiasis. Journal of Genetic Engineering and Biotechnology 2007; 5(12):1-8.

Murakami Y, Yasuda T, Saigo K, et al. Comprehensive analysis of microRNA expression patterns in hepatocellular carcinoma and non-tumorous tissues. Oncogene 2006; 25:2537-2545.

Nguyen-Khac E, Capron D. Noninvasive diagnosis of liver fibrosis by ultrasonic transient elastography (Fibroscan). Eur J Gastroenterol Hepatol 2006; 18:1321-1325.

Paynord T, Bedossa P, Opolon P. Natural history of liver fibrosis progression in patients with chronic hepatitis C.The OBSVIRC, METAVIR, CLINIVIR, and DOS VIRC groups. Lancet 1997; 349:82532.

Poynard T, Mathurin P, Lai CL, Guyader D, Poupon R, Tainturier $\mathrm{MH}$, et al. A comparison of fibrosis progression in chronic liver diseases. J Hepatol 2003; 38:257-265.

Proctor, R. A. Fibronectin: A brief overview of its structure, function and physiology. Reviews of Infectious Diseases 9 Suppl 1987; 4:S317S321.

S. Jung, G. Jung, A. Tranzer, R. Dörr: Plasma fibronectin changes in various cancers. La presse medicale, 1986; 15: $197-204$.

Saiki, R.K., Gelfand, D.H., Stoffel, S., Scharf, S.J., Higuchi, R., Horn, G.T., Mullis, K.B. and Erlich, H.A. Primer-directed enzymatic amplification of DNA with a thermostable DNA polymerase. Science 1988; 239:487491.

Sato $\mathrm{Y}$, et al. Early recognition of hepatocellular carcinoma based on altered profiles of alphafetoprotein. New Engl J Med, 1993; 328, 25:1802-1806.

Schmittgen TD, Livak KJ. Analyzing real-time PCR data by the comparative $\mathrm{C}$ (T) method. Nat Protoc, 2008; 3: 1101-1108.

Scholz A, Rehm VA, Rieke S et al. Angiopoietin -2 serum levels are elevated in patients with liver cirrhosis and hepatocellular carcinoma. Am J Gastroentrol 2007; 102:2471- 2481.

Schuppan D, Afdhal NH. Liver cirrhosis. Lancet 2008; 371:838-851.

Shan Y, Zheng J, Lambrecht RW, Bonkovsky HL. Reciprocal effects of micro-RNA-122 on expression of heme oxygenase-1 and hepatitis $\mathrm{C}$ virus genes in human hepatocytes. Gastroenterology 2007; 133: 1166-1174.

Tangkijvanich P, Anukulkamkusol N, Suwangool $\mathrm{P}$, Lert-maharit $\mathrm{S}$, Hanvivatvong $\mathrm{O}$, Kullavanijaya $P$, et al. Clinical characteristics and prognosis of hepatocellular carcinoma: analysis based on serum alpha-fetoprotein levels. J Clin Gastroenterol 2000; 31:302-8. 
Ura S, Honda M, Yamashita T et al. Differential microRNA expression between hepatitis $B$ and hepatitis $C$ leading disease progression to hepatocellular carcinoma. Hepatology 2009; 49:1098-1112.

Varnholt H, Drebber U, Schulze F, Wedemeyer I, Schirmacher $\mathrm{P}$, Dienes HP, Odenthal M. MicroRNA gene expression profile of hepatitis C virus-associated hepatocellular carcinoma. Hepatology 2008; 47(4):1223-32.

Wang K, Zhang S, Weber J, Baxter D, Galas DJ Export of microRNAs and microRNAprotective protein by mammalian cells. Nucl Acids Res 2010; 38: 7248-7259.
Xu J, Wu C, Che X, Wang L, Yu D, et al. Circulating microRNAs, miR- 21, miR-122, and miR-223, in patients with hepatocellular carcinoma or chronic hepatitis. Mol Carcinog 2011; 50: 136-142.

Yang S Z, Dong J H, Li K et al. Detection of AFP mRNA and MAGE1-mRNA as markers of disseminated hepatocellular carcinoma cells in blood Hepatobiliary Pancreatic Dis Int, 2005; 4 (2):227-233.

Zhang Y, Jia Y, Zheng R, Guo Y, Wang Y, et al. Plasma microRNA-122 as a biomarker for viral-, alcohol-, and chemical-related hepatic diseases. Clin Chemo 2010; 56: 1830-1838 